\title{
Green Synthesis and Characterization of Anticancer Effected Silver Nanoparticles with Silverberry (Elaeagnus angustifolia) Fruit Aqueous Extract
}

\author{
Omer Erdogan ${ }^{1}$, Salih Pasa ${ }^{2}$, Ozge Cevik ${ }^{1 *}$ \\ ${ }^{1}$ Aydin Adnan Menderes University, School of Medicine, Department of Biochemistry, Aydin Turkey \\ ${ }^{2}$ Afyon Kocatepe University, Faculty of Education, Department of Science, Afyonkarahisar, Turkey \\ omer.erdogan@adu.edu.tr ${ }^{\mathbb{D}}$,drsalihpasa@gmail.com ${ }^{\mathbb{D}}$,*drozgecevik@gmail.com $\mathbb{D}$ \\ Received date:13.04.2021, Accepted date: 28.07.2021
}

\begin{abstract}
Cancer is the deadliest health problem after cardiovascular system diseases. New strategies have been developed over the years in the fight against cancer. Silver nanoparticles are one of these approaches. In this study, it was aimed to synthesize silver nanoparticles with the green approach using Elaeagnus angostifolia aqueous extract and to investigate the cytotoxic effects of these nanoparticles. Silver nanoparticles have been characterized by analytical methods such as UV-Vis, FTIR, SEM, EDX. The peak around $3 \mathrm{keV}$ in the EDX spectrum confirms the synthesis of silver nanoparticles. In vitro cytotoxic activity of silver nanoparticles was tested on human prostate cancer cell line PC3, human cervical cancer cell line HELA and normal mouse fibroblast cell line L929. It has been found that silver nanoparticles synthesized with the aqueous extract of Elaeagnus angustifolia showed a dose-dependent cytotoxic effect on HELA and PC3 cells.
\end{abstract}

Keywords: Anti-cancer, Elaeagnus angustifolia, green synthesis, silverberry, silver nanoparticles

\section{Antikanser Etkili Gümüş Nanopartiküllerinin İğde (Elaeagnus angustifolia) Meyvesi Sulu Ekstraktı ile Yeşil Sentezi ve Karaktarizasyonu}

$\ddot{\mathbf{O} z}$

Kanser kardiyovasküler sistem hastalıklarından sonra gelen en ölümcül sağlık problemidir. Kanserle mücadelede yıllar içerisinde yeni stratejiler geliştirilmiştir. Gümüş nanopartikülleri bu yaklaşımlardan bir tanesidir. Bu çalışmada Elaeagnus angostifolia sulu ekstraktı kullanılarak gümüş nanopartiküllerinin yeşil sentezi ve bu nanopartiküllerin sitotoksik etkilerinin belirlenmesi amaçlanmıştır. Gümüş nanopartikülleri UV-Vis, FTIR, SEM, EDX gibi analitik metotlar ile karakterize edilmiştir. EDX spektrumunda $3 \mathrm{keV}$ civarındaki pik gümüş nanopartiküllerinin sentezini doğrulamaktadır. Gümüş nanopartiküllerinin in vitro sitotoksik aktivitesi insan prostat kanser hücre hattı PC3, insan serviks kanseri hücre hattı HELA ve normal mouse fibroblast hücre hattı L929 üzerinde test edilmiştir. Elaeagnus angustifolia sulu ekstraktı ile sentezlenen gümüş nanopartiküllerinin HELA ve PC3 hücreleri üzerinde doza bağımlı sitotoksik etki gösterdiği bulunmuştur.

Anahtar Kelimeler: Anti-kanser, Elaeagnus angustifolia, yeşil sentez, iğde, gümüş nanopartikülleri

\section{INTRODUCTION}

Cancer is one of the most important health problems threatening human life and ranks second worldwide after cardiovascular system diseases among the deaths whose cause is known (Siegel et al., 2019). Chemotherapy, which is the main strategy used in the fight against cancer, can be used alone or in combination with various treatment approaches (Hassanpour and Deghdani, 2017). Studies on the use of silver nanoparticles in cancer treatment have gained momentum in recent years (Jeyeraj et al., 2013).

Silver nanoparticles have succeeded in attracting the attention of the scientific world due to their superior physical, chemical and biological properties compared to other metal nanoparticles. Studies on the use of silver nanoparticles in medicine as anti-microbial, anti-fungal and anticancer agents are continuing intensively (Prabhu and Poulouse, 2012; Öztürk et al., 2020; Mohammed et 
al., 2020). There are three basic approaches in the synthesis of silver nanoparticles: physical, chemical, and biological. Since physical and chemical methods have some disadvantages such as expensive equipment, waste of time and the use of toxic materials, biological methods are more preferred in the synthesis of silver nanoparticles (Erdoğan et al., 2019; Zhang et al., 2021). Biocomponents found in biological materials play a role in synthesis reactions as reducing agents and reduce silver ions to metallic silver nanoparticles. Bacteria, fungi, algae and various plant components are used in biological synthesis (Wei et al., 2015). Since this method is environmentally and nature friendly, it is also called "Green Synthesis" in the literature. Plant extracts are a more ideal material in the green synthesis of nanoparticles since they do not have any contamination risk (Beykaya and Çağlar, 2016).

Elaeagnus angustifolia, known as İğde in our country and known as Russian olive throughout the world, grows especially in Asia and Europe. Especially in Middle Eastern countries, silverberry fruit is frequently used in wound healing, antiulcerogenic, anti-inflammatory, anti-emetic treatments and traditional medicine (Natanzi et al., 2012; Gurbuz et al., 2003; Ahmadiani et al., 2000; Rasekhi et al., 1999). Elaeagnus angustifolia fruit extract has been reported to contain various metabolites such as phytosterols, flavonoids, phenolic acids and terpenoids (Azez et al., 2018; Tepe and Doyuk, 2020). It is known that this rich metabolite content facilitates the reduction and stabilization of metal ions in nanoparticle synthesis (Baran, 2019).

In this study, it was aimed to synthesize silver nanoparticles with the green approach using Elaeagnus angostifolia aqueous extract and to investigate the cytotoxic effects of these nanoparticles. The synthesized nanoparticles were characterized by Ultraviolet-Visible Spectroscopy (UV-Vis), Infrared Spectroscopy (FTIR), Scanning Electron Microscopy (SEM), Energy Dispersive XRay (EDX) Spectroscopy. In addition, cytotoxic effects of silver nanoparticles on human cervical cancer cells (HELA), human prostate cancer cells (PC3) and mouse fibroblast cells (L929) were investigated.

\section{MATERIAL AND METHODS \\ Preparation of Elaeagnus Angustifolia Fruit Aqueous Extract}

The fruits of Elaeagnus angustifolia, which grows in stony soil at Aydin Adnan Menderes University Central Campus $\left(37^{\circ} 51^{\prime} 15^{\prime} \mathrm{N}\right.$ $\left.27^{\circ} 51^{\prime} 22^{\prime \prime} \mathrm{E}\right)$ were freshly picked in October 2020. The seed part of the fruit was discarded, and the pulp part was used for extraction (Figure 1). $100 \mathrm{~g}$ of fruit pulp was weighed and transferred to a $500 \mathrm{~mL}$ conical flask. $200 \mathrm{~mL}$ of distilled water was added on it. This mixture was heated on magnetic stirrer at $100{ }^{\circ} \mathrm{C}$ for 2 hours. After this process, the mixture could come to room temperature and filtered with Whatman filter paper (Grade 1). The filtrate was stored in a refrigerator at $+4{ }^{\circ} \mathrm{C}$ until it was used in nanoparticle synthesis (Rao et al., 2015).

\section{Green Synthesis of Silver Nanoparticles}

$20 \mathrm{~mL}$ of silver nitrate solution $(10 \mathrm{mM})$ was added to the beaker. $20 \mathrm{~mL}$ of Elaeagnus angustifolia fruit aqueous extract was added drop by drop with the help of a pasteur pipette and kept in an ultrasonic bath for 10 minutes. The reaction mixture was exposed to $360 \mathrm{~W}$ microwave rays for 5 minutes. The mixture in the beaker was transferred to falcon tubes and centrifuged at $4000 \mathrm{rpm}$ for 10 minutes. Since the supernatant was seen to be clear, it was concluded that the particulate precipitation was complete. The pellet part containing the precipitated particles was washed 3 times with cold ethanol in order to remove organic residues from the extract. After the falkon tube was centrifuged again at 4000 rpm for 10 minutes, the pellet part was collected and left to dry overnight in a $100{ }^{\circ} \mathrm{C}$ oven. The obtained silver nanoparticles were stored in eppendorf tubes at room temperature to be used in characterization and cytotoxicity experiments (Joseph and Mathew, 2015; Haris et al., 2017).

\section{Characterization of Silver Nanoparticles}

The UV-Vis spectrum of the synthesized silver nanoparticles was taken with an Ultraviolet visible (UV-Vis) spectrophotometer (Thermo Scientific Multiscan Spectrum 1500) in the range of 200-800 $\mathrm{nm}$. Functional group analysis of silver nanoparticles was performed by making measurements in the range of $400-4000 \mathrm{~cm}^{-1}$ with a Fourier-transform infrared (FT-IR) spectrophotometer (Shimadzu IR 8000). The structural properties and surface morphological properties of the nanoparticles were determined by examining the micrographs taken from the scanning electron microscope (SEM) (LEO 1430 VP). In addition, elemental composition 
analyzes of silver nanoparticles were analyzed by Energy Dispersion X-Ray (EDX) spectroscopy (LEO 1430 VP). To obtain SEM image and EDX analysis; the sample of silver nanoparticles were coated with gold under $4 \times 10^{-2}$ mbar pressure by sputtering technique to make them better conductor. Then, the SEM images were collected at $1.3 \times 10^{-5}$ pressure. The EDX analysis was recorded by local mapping technique from the best captured image.

\section{Cell Culture Studies}

In this study, HELA human cervical cancer, PC3 human prostate cancer and L929 mouse fibroblast cells belonging to the American Type Culture Collection were used to determine the cytotoxic effects of the synthesized silver nanoparticles. DMEM medium containing 10\% FBS (Sigma F2442), 2mM L-glutamine (Sigma G-6392), 100 $\mathrm{U} / \mathrm{mL}$ penicillin and $100 \mu \mathrm{g} / \mathrm{mL}$ streptomycin was used for the growth of HELA and L929 cells. PC3 cells were cultured in RPMI-1640 medium containing 10\% FBS (Sigma F-2442), 2mM Lglutamine (Sigma G-6392), $100 \mathrm{U} / \mathrm{mL}$ penicillin and $100 \mu \mathrm{g} / \mathrm{mL}$ streptomycin. Cells extracted from liquid nitrogen were planted in $75 \mathrm{~cm}^{2}$ flasks and grown in an oven with $5 \% \mathrm{CO}_{2}$ (Core EC-160) at $37^{\circ} \mathrm{C}$ until the cells became a full layer. When the flask base was filled to $90 \%$, the cells were removed with $0.05 \%$ Trypsin-EDTA (Sigma T-4049) and passaged (Cevik et al., 2020).

\section{MTT measurements}

The MTT test is widely used as a fast and sensitive method in evaluating the cytotoxicity of anticancer agents (Wan et al., 1994). The working principle of this method is the disintegration of the tetrazolium ring of the MTT dye into formazan by means of the succinate dehydrogenase enzyme in the intact mitochondria of the cells (Baek et al., 1998). To determine the cytotoxic effect of silver nanoparticles, cells were seeded in 96-well cell culture plates at a density of $1 \times 10^{4}$ per well in 100 $\mu \mathrm{L}$ medium. In order to adhere the cells to the plate base, incubation was carried out in an oven with 5\% $\mathrm{CO}_{2}$ at $37^{\circ} \mathrm{C}$. After adding different concentrations of silver nanoparticles $(1,10,100,1000 \mu \mathrm{g} / \mathrm{mL})$ to the cells, the plate was re-incubated for 24 hours. The medium from the wells was discarded and 100 $\mu \mathrm{L}$ of fresh medium was added to each well. $10 \mu \mathrm{L}$ of the previously prepared MTT dye was added to all wells. After the cells were incubated for 4 hours, the medium was decanted and $100 \mu \mathrm{L}$ of dimethyl sulfoxide was added to each well to dissolve the formazan dye formed. The intensity of the formed color was measured at $570 \mathrm{~nm}$ in a microplate reader (Biotek Co., USA). Cell viability \% was calculated with the aid of equation 1 and IC50 values using GraphPad Prism program (Cevik et al., 2018).

$\%$ Cell viability $=(\mathrm{OD}$ test sample $) /(\mathrm{OD}$ control) X 100

(Eq. 1)

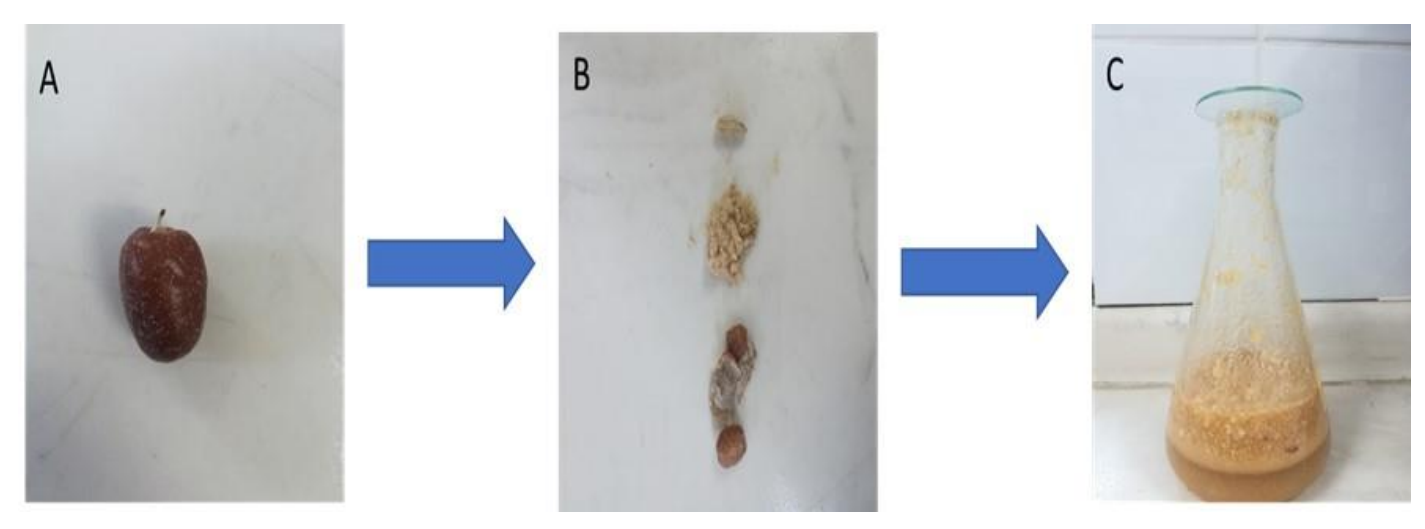

Figure 1: A) Elaeagnus angustifolia fruit. B) The part of Elaeagnus angustifolia fruit. C) The preparation of Elaeagnus angustifolia fruit aqueos extract 


\section{Statistical analysis}

Data from three independent experiments are presented as mean \pm SD. Differences between groups were analyzed by student's t test. Statistical analysis was performed using GraphPad Prism version 5.0 software. Statistical significance is defined as follows: *, $\mathrm{p} \leq 0.05 ; * *, \mathrm{p} \leq 0.01 ; * * *$, $\mathrm{p} \leq 0.001$.

\section{RESULTS AND DISCUSSION}

Synthesis and Characterization of Silver Nanoparticles

The use of green synthesis, which is a nature and life-friendly method that does not require the use of toxic chemicals in the synthesis of nanoparticles, has become a popular field of study (Ong et al., 2013).

In this study, silver nanoparticles were synthesized from green synthesis using Elaeagnus angustifolia fruit aqueous extract. Thus, a more advantageous method was preferred in terms of cost, time, environment, and health. In the characterization and structural analysis of silver nanoparticles, various analytical methods such as ultraviolet-visible region (UV-Vis) spectroscopy, fourier transform infrared (FTIR) spectroscopy, scanning electron microscopy (SEM), energy dispersion X-ray (EDX) spectroscopy and elemental analysis are used.

Ultraviolet-visible spectroscopy (UV-Vis) is one of the most important methods used in the characterization of silver nanoparticles. The most important indicator confirming the synthesis of silver nanoparticles is the color of the solution that turns brown during the reaction. This color formation is due to the surface plasmon resonance of the silver nanoparticles (Darroidi et al., 2010). The increase in absorbance between $420-470 \mathrm{~nm}$ in the UV spectrum is due to the surface plasmon resonance of silver nanoparticles (Bhui et al., 2009). Nahar et al. (2021) stated that the maximum absorbance at $442 \mathrm{~nm}$ wavelength was observed in the UV spectrum of silver nanoparticles synthesized with Citrus sinensis extract. When looking at the UV graph of silver nanoparticles synthesized with the aqueous extract of the silverberry fruit, $\lambda \max$ was obtained at $432 \mathrm{~nm}$ (Figure 2). On the other hand, the appearance peak at the about $250 \mathrm{~nm}$ is probably comes from the presence heteroatoms such as $\mathrm{N}, \mathrm{O}$ (Njoku et al., 2013).

Figure 2: UV-Vis spectrum of silver nanoparticles synthesized with aqueous extract of Elaeagnus angustifolia

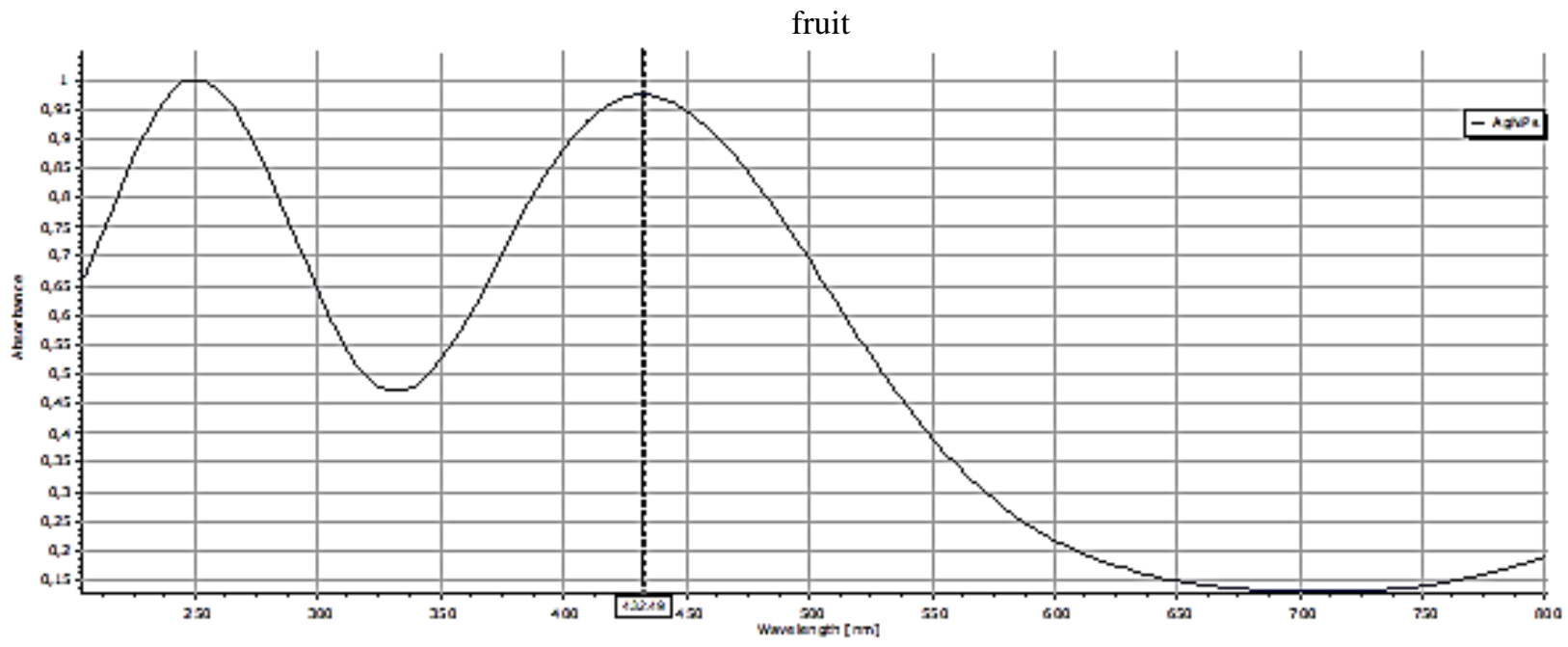

In the green synthesis of silver nanoparticles, the bio-reducing agents contained in the extracts are adsorbed on the surface of the nanoparticles. Functional group analysis of these biocomponents on the surface of nanoparticles is determined by
FTIR spectroscopy. When the FTIR spectrum of the silver nanoparticles synthesized with the aqueous extract of the silverberry is examined, bands are seen at 3410, 2918, 2850, 2360, 1739, 1622 and $669 \mathrm{~cm}^{-1}$ (Figure 


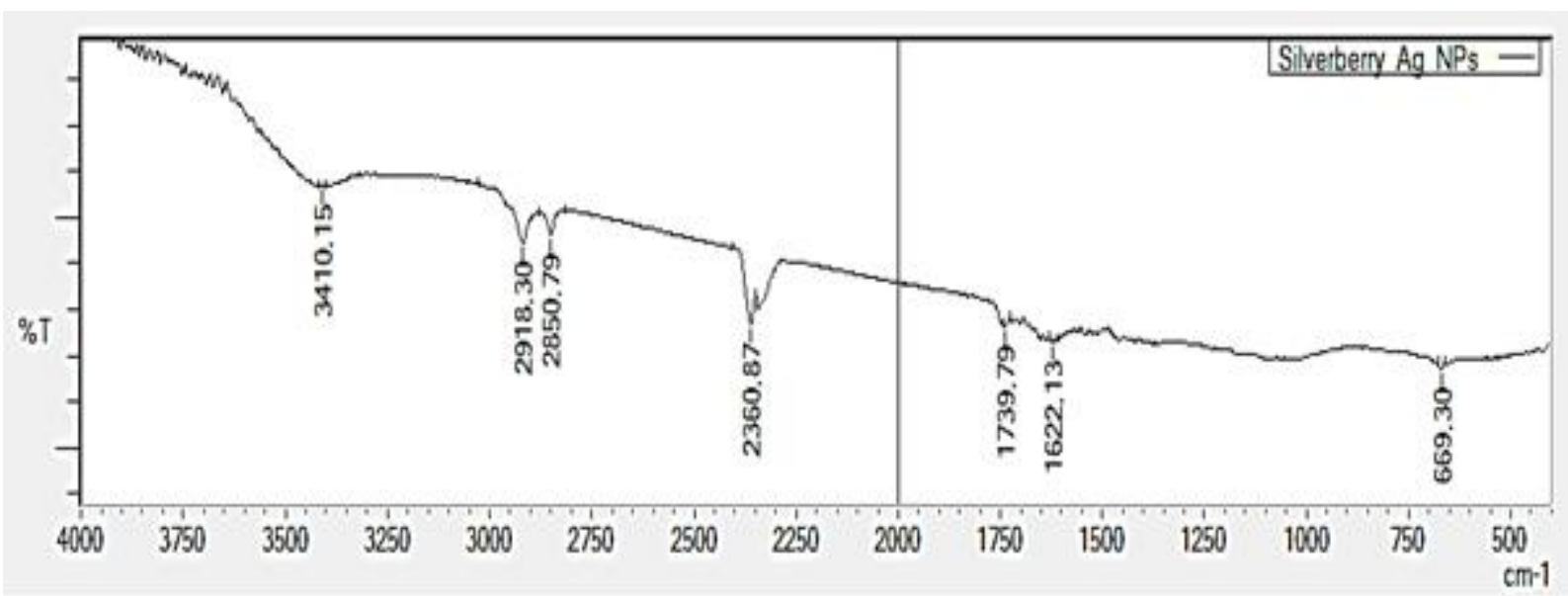

Figure 3: FTIR spectrum of silver nanoparticles synthesized with aqueous extract of Elaeagnus angustifolia fruit

The broad band at $3410 \mathrm{~cm}^{-1}$ belongs to the O$\mathrm{H}$ stretch. The peak at $2360 \mathrm{~cm}^{-1}$ is due to atmospheric carbon dioxide. The peak at $669 \mathrm{~cm}^{-1}$ is the vibrations of silver (Banerjee and Nath, 2015; Balashanmugan and Kalaichelvan, 2015).
Morphological properties of silver nanoparticles are examined by scanning electron microscopy. When the SEM micrograph of the silver nanoparticles is examined (Figure 4), nano-sized particles are seen, most of which are spherical and

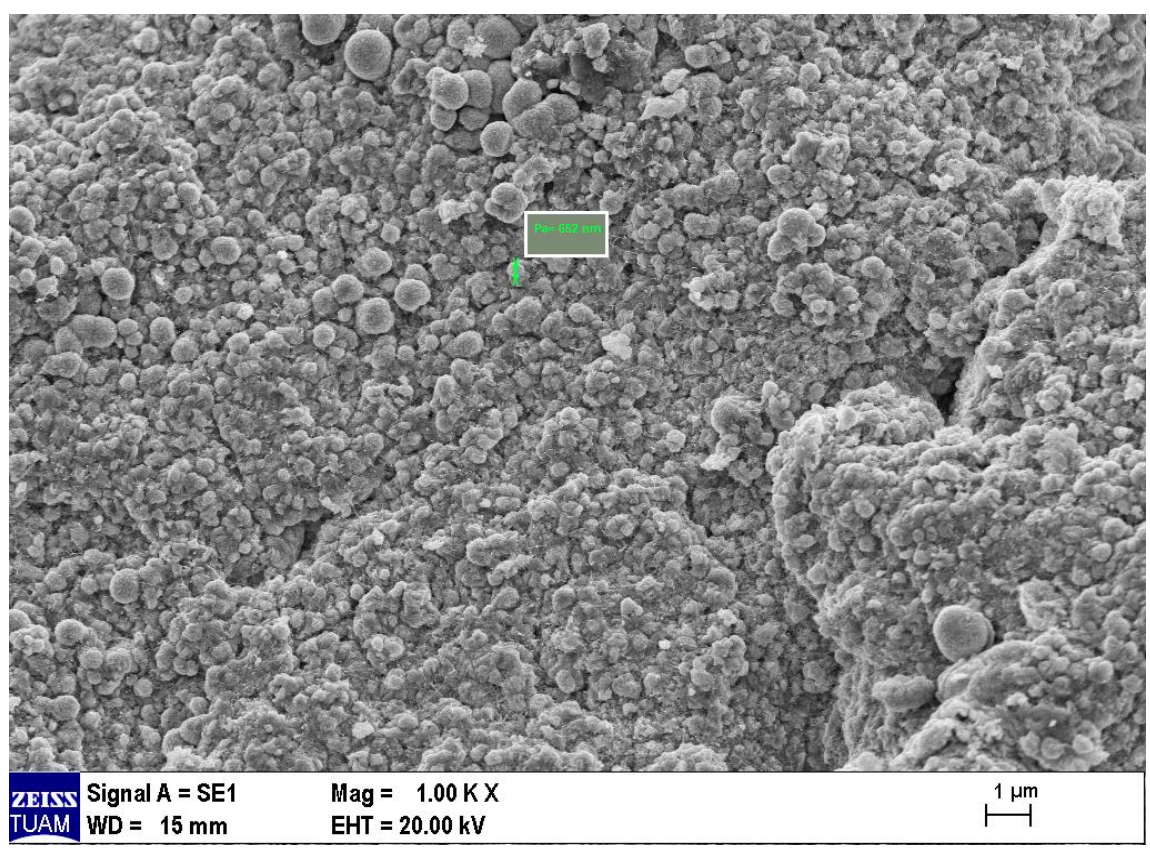

Figure 4: SEM micrograph of silver nanoparticles synthesized with the Elaeagnus angustifolia fruit aqueous extract

some of them irregularly shaped. It has also been determined that these nanoparticles form micronsized aggregates. The approximate sizes of nanoparticles were found to be $652 \mathrm{~nm}$.
Energy dispersion X-Ray crystallography is an analytical method used to determine the elemental composition of silver nanoparticles. In the EDX spectrum, the peak around $3 \mathrm{keV}$ confirms the presence of silver (Govarthanan et al., 2014). When 
the EDX spectrum of the synthesized nanoparticle is examined (Figure 5A), the peak around $3 \mathrm{keV}$, supports the synthesis of silver nanoparticles. The abundance of silver atom was found to be $82.32 \%$.
Other contaminants such as carbon and nitrogen probably were caused by Elaeagnus angustifolia residues (Figure 5B).

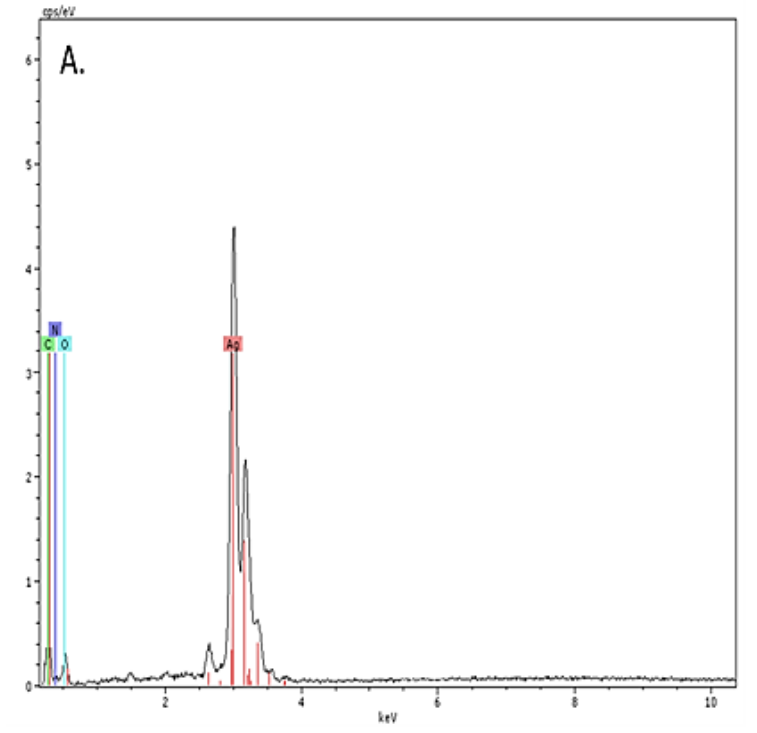

B.

Element Series Net unn. C norm. C Atom. C Oxid Oxid. C

\begin{tabular}{|c|c|c|c|c|c|c|}
\hline & & wt.-\%] [ & [wt.-\%] & [at.-\%] & 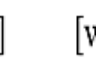 & wt.-\%] \\
\hline $\begin{array}{l}\text { Carbon } \\
6.46\end{array}$ & K series & 2018 & 3.72 & 1.69 & 6.52 & $\mathrm{CO}_{2}$ \\
\hline $\begin{array}{l}\text { Nitrogen } \\
11.22\end{array}$ & $\mathrm{~K}$ series & 400 & 15.07 & 6.84 & 22.68 & $\mathrm{~N}_{2} \mathrm{O}$ \\
\hline $\begin{array}{l}\text { Silver } \\
82.32\end{array}$ & L series & 61701 & 173.72 & 78.79 & $\begin{array}{ll}9 & 33.9\end{array}$ & $94 \mathrm{Ag}$ \\
\hline
\end{tabular}

Figure 5: A) EDX spectrum of silver nanoparticles synthesized with Elaeagnus Angustifolia fruit aqueous extract.

B) Elemental analysis results

\section{Cytotoxic Effects of Silver Nanoparticles}

Cancer is a health problem that is difficult to treat and has a high mortality compared to other diseases. Current chemotherapeutic drugs such as cisplatin, doxorubicin, taxol and bleomycin bring some adverse conditions such as low specificity, high cost, high toxicity, undesirable side effects and drug resistance. Development of new treatment methods becomes necessary to overcome these disadvantages (Erdoğan, 2018; Wafa and Ghareib, 2018). Scientific research on the synthesis, characterization, stability, formulation and delivery of nanoparticles as cytotoxic agent and drug delivery system in cancer treatment continues intensively.

It has been reported that silver nanoparticles synthesized by green synthesis have better cytotoxic effects than chemically synthesized ones. It is thought that this effect is due to the biocomponents contained in the biological material used in the synthesis (Kummara et al., 2016). For this reason, the cytotoxic effects of silver nanoparticles synthesized with different plant extracts are investigated on various cell lines. Selvan et al. (2018) investigated the cytotoxic effects of silver nanoparticles synthesized with carnelia sinensis extract on MCF7, HELA, HepG2, A549 and NHDF cells. They found the IC50 values of silver nanoparticles on these cells as 19.94, 16.75, 27.63, 13.26 and $>100$, respectively. In our study, cytotoxic effects of silver nanoparticles synthesized with the aqueous fruit extract of Elaeagnus angustifolia were investigated on HELA and PC3 as cancerous cells and on L929 as normal mouse fibroblast cells. IC50 value of a potential chemotherapeutic agent is expected to be low in cancer cells and high in normal cells (Damiani et al., 2019). IC50 values of silver nanoparticles for HELA, PC3 and L929 cells were calculated as $11.8,18.8$ and $13.6 \mu \mathrm{g} / \mathrm{mL}$, respectively (Figure $6 \mathrm{~A}$ ). 
A.

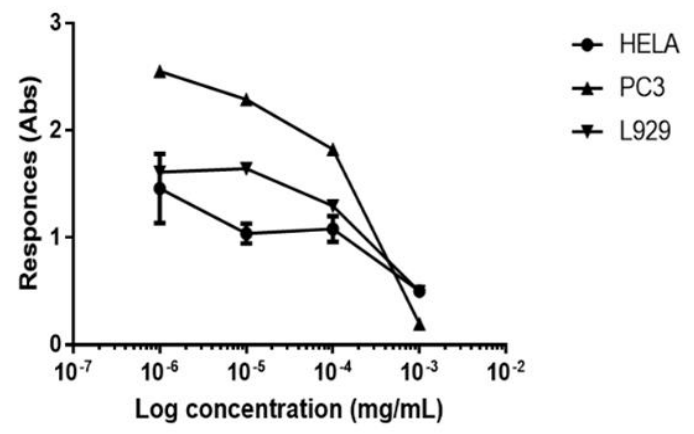

B.

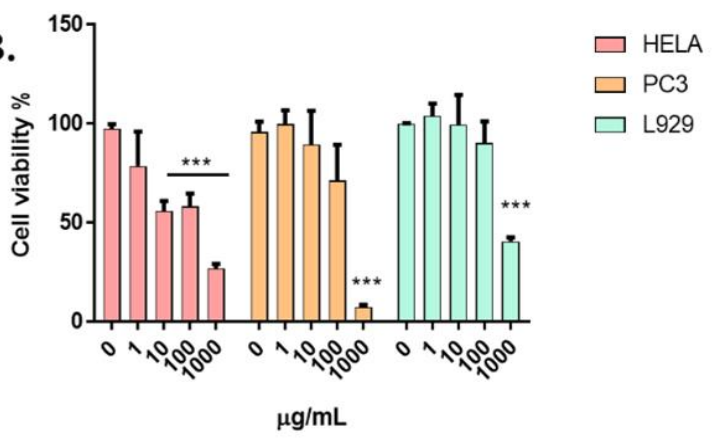

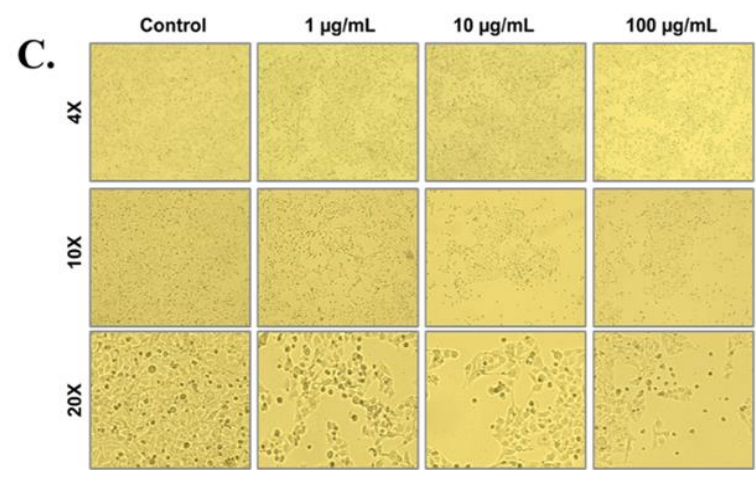

Figure 6: A) IC50 plots of HELA, PC3 and L929 cells treated with silver nanoparticles. B) Cell viability graphs of HELA, PC3 and L929 cells treated with silver nanoparticles. C) Inverted microscope images of HELA cervical cancer cells treated with silver nanoparticles

These results clearly show that the IC50 value of the silver nanoparticle synthesized with Elaeagnus angustifolia is lower compared to other studies. Bioactive compounds from Elaeagnus angustifolia may have increased the cytotoxic activity of silver nanoparticles. When the cell viability graph was examined (Figure 6B), it was found that silver nanoparticles decreased the proliferation of PC3 and L929 cells in a dosedependent manner. Especially, $1000 \mu \mathrm{g} / \mathrm{mL}$ dose reduced the viability of PC3 prostate cancer cells up to $10 \%$. The IC50 value of silver nanoparticles was found to be the lowest in HELA cells. Therefore, the morphological effects of these nanoparticles on HELA cervical cancer cells were examined with images taken at $4 \mathrm{X}, 10 \mathrm{X}$ and $20 \mathrm{X}$ magnification (Figure 6C). HELA cells treated with $100 \mu \mathrm{g} / \mathrm{mL}$ silver nanoparticles were found to exhibit apoptotic markers such as cell size reduction and bubbling in the plasma membrane.

\section{CONCLUSION}

The use of nanotechnological metal atoms both as cytotoxic agents and as a carrier system in cancer treatment is increasing day by day. With this study, silver nanoparticles were synthesized with green synthesis, which is a time-saving, less costly, environmentally friendly and more easily applicable method. In addition, these biogenic silver nanoparticles have the potential to be used as an anticancer agent in the treatment of cervical and prostate cancer due to their cytotoxic effect on HELA and PC3 cells.

\section{ACKNOWLEDGMENT}

This work was supported by Adnan Menderes University Research Grant (ADU-MARL-18001, ADU TPF-19037).

\section{CONFLICT OF INTEREST}

The Author report no conflict of interest relevant to this article 


\section{RESEARCH AND PUBLICATION ETHICS STATEMENT}

The author declares that this study complies with research and publication ethics.

\section{REFERENCES}

Ahmadiani, A., Hosseiny, J., Semnanian, S., Javan, M., Saeedi, F. ... Saremi, S. (2000). Antinociceptive and anti-inflammatory effects of Elaeagnus angustifolia fruit extract. Journal of Ethnopharmacology, (1-2), 287-92.

Azez, R.A., Abaas, I.S. and Kadhim, E.J. (2018). Isolation and characterization of $\beta$-sitosterol from elaeagnus angustifolia cultivated in iraq. Asian Journal of Pharmaceutical and Clinical Research, 11(11), 442-446.

Baek, S.H., Kim, Y.O., Kwag, J.S., Choi, K.E., Jung, W.Y. and Han, D.S. (1998). Boron trifluoride etherate on silica-A modified Lewis acid reagent (VII). Antitumor activity of cannabigerol against human oral epitheloid carcinoma cells. Archives of Pharmacal Research, 21(3), 353-356.

Balashanmugam, P. and Kalaichelvan, P.T. (2015). Biosynthesis characterization of silver nanoparticles using Cassia roxburghii DC. Aqueous extract and coated on cotton cloth for effective antibacterial activity. International Journal of Nanomedicine, 10(1), 87-97.

Banerjee, P. and Nath, D. (2015). A Phytochemical Approach to Synthesize Silver Nanoparticles for Non-Toxic Biomedical Application and Study on their Antibacterial Efficacy. Nanoscience \& Technology, 2(1), 1-14.

Baran MF. (2019). Prunus avium kiraz yaprağı özütü ile gümüş nanopartikül (AgNP) sentezi ve antimikrobiyal etkisinin incelenmesi. Dicle Üniversitesi Mühendislik Fakültesi Dergisi, 10(1), 221-227.

Beykaya, M. and Çağlar, A. (2016). Bitkisel Özütler Kullanılarak Gümüş-Nanopartikül (AgNP) Sentezlenmesi ve Antimikrobiyal Etkinlikleri Üzerine Bir Araştırma. Afyon Kocatepe Üniversitesi Fen ve Mühendislik Bilimleri Dergisi, 16(3), 631641.

Bhui, D.K., Bar, H., Sarkar, P., Sahoo, G.P., Prasad De S. and Misra, A. (2009). Synthesis and UV-vis spectroscopic study of silver nanoparticles in aqueous SDS solution. Journal of Molecular Liquids, 145(1), 33-37.
Cevik, O., Acidereli, H., Turut, F.A., Yildirim, S. and Acilan, C. (2020). Cabazitaxel exhibits more favorable molecular changes compared to other taxanes in androgen-independent prostate cancer cells. Journal of Biochemical and Molecular Toxicology, 34(9), e22542.

Cevik, O., Turut, F.A., Acidereli, H. and Yildirim, S. (2018). Cyclosporine-A induces apoptosis in human prostate cancer cells PC3 and DU145 via downregulation of COX-2 and upregulation of TGF $\beta$. Turkish Journal of Biochemistry, 44(1), 4754.

Damiani, E., Solorio, J.A., Doyle, A.P. and Wallace, H.M. (2019). How reliable are in vitro IC50 values? Values vary with cytotoxicity assays in human glioblastoma cells. Toxicology Letters, 302, 28-34.

Darroidi, M., Ahmad, M.B., Abdullah, A.H., Ibrahim, N.A. and Shameli, K. (2010). Effect of Accelerator in Green Synthesis of Silver Nanoparticles. International Journal of Molecular Science, 11(10), 3898-3905.

Erdoğan, O., Birtekocak, F., Oryașın, E., Abbak, M., Demirbolat, G.M. ... Çevik Ö. (2019). Enginar Yaprağı Sulu Ekstraktı Kullanılarak Çinko Oksit Nanopartiküllerinin Yeşil Sentezi, Karakterizasyonu, Anti-Bakteriyel ve Sitotoksik Etkileri. Düzce T1p Fakültesi Dergisi, 21(1), 19-26.

Erdoğan, Ö. (2018). Aminoasit temelli amitlerin sentezlenmesi ve bu bileşiklerin HELA serviks kanser hücreleri üzerinde antikanser etkilerinin incelenmesi. (Yayımlanmış Yüksek Lisans Tezi). Adnan Menderes Üniversitesi Sağlık Bilimleri Enstitüsü, Aydın.

Govarthanan, M., Selvankumar, T., Manoharan, K., Rathika, R., Shanthi, K. ... Oh B.T. (2014). Biosynthesis and characterization of silver nanoparticles using panchakavya, an Indian traditional farming formulating agent. Int $\mathbf{J}$ Nanomedicine, 9, 1593-1599.

Gurbuz, I., Ustun, O., Yesilada, E., Sezik, E. and Kutsal, O. (2003). Anti-ulcerogenic activity of some plants used as folk remedy in Turkey. Journal of Ethnopharmacology, 88(1), 93-97.

Haris, M., Kumar, A., Ahmad, A., Abuzinadah, F., Basheikh, M. ... Mujeeb, M. (2017). Microwaveassisted green synthesis and antimicrobial activity of silver nanoparticles derived from a supercritical carbon dioxide extract of the fresh aerial parts of Phyllanthus niruri L. Tropical Journal of Pharmaceutical Research, 16(12), 2967-2976. 
Hassanpour, S.H. and Dehghani, M. (2017). Rewiew of cancer from perspective of molecular. Journal of Cancer Research and Practise, 4, 127-129.

Jeyeraj, M., Sathishkumar, G., Sivanandhan, G., Mubarak, A.D., Rajesh, M. ... Ganapathi, A. (2013). Biogenic silver nanoparticles for cancer treatment: An experimental report. Colloids and Surfaces B: Biointerfaces, 106, 86-92.

Joseph, S. and Mathew, B. (2015). Microwave-assisted green synthesis of silver nanoparticles and the study on catalytic activity in the degradation of dyes. Journal of Molecular Liquids, 204, 184-191.

Kummara, S, Patil, M.B. and Uriah, T. (2016). Synthesis, characterization, biocompatible and anticancer activity of green and chemically synthesized silver nanoparticles - A comparative study. iomedicine \& Pharmacotherapy, 84, 10-21.

Mohammed, S.S.S., Lawrence, A.V., Sampath, S., Sunderam, V. and Madhavan, Y. (2020). Facile green synthesis of silver nanoparticles from sprouted Zingiberaceae species: Spectral characterisation and its potential biological applications. Materials Technology, 1, 1-15.

Nahar, K., Rahaman, H., Khan, A., Islam, K. and AlReza, S. (2021). Green synthesis of silver nanoparticles from Citrus sinensis peel extract and its antibacterial potential. Asian Journal of Green Chemistry, 5, 135-150.

Natanzi, M.M., Pasalar, P., Kamalinejad, M., Dehpour, A.R., Taganvar, S.Y. ... Nejad, S.G. (2012). Effect of Aqueous Extract of Elaeagnus angustifolia Fruit on Experimental Cutaneous Wound Healing in Rats. Acta Medica Iranica, 50(9), 589-596.

Njoku, D.I., Chidiebere, M.A., Oguzie, K.L., Ogukwe, C.E. and Oguzie, E.E. (2013). Corrosion inhibition of mild steel in hydrochloric acid solution by the leaf extract of Nicotiana tabacum. Advances in Materials and Corrosion. 1, 54-61.

Ong, C., Lim, J.Z.Z., Ng, C.T., Li, J.J., Yung, L.Y.L. and Bay, B.H. (2013). Silver Nanoparticles in Cancer: Therapeutic Efficacy and Toxicity. Current Medicinal Chemistry, 20(6), 772-781.

Öztürk, B.Y. and Öztürk, D. (2020). Tilia rubra DC. ekstraktı kullanılarak gümüş nanopartikülün hücre dışı biyosentezi ve antifungal aktivitesi. Biyoçeşitlilik ve Koruma, 13(3), 244-251.

Prabhu, S. and Poulose, E.K. (2012). Silver nanoparticles: mechanism of antimicrobial action, synthesis, medical applications, and toxicity effects. International Nano Letters, 2(32), 1-10.
Rao, K.G., Ashok, C.H., Rao, K.V., Chakra, C.H.S. and Akshaykranth, A. (2015). Eco-friendly synthesis of $\mathrm{MgO}$ nanoparticles from orange fruit waste. International Journal of Applied Physics and Science, 2(3), 1-6.

Rasekhi, H.R., Kamali, M., Hosseini, S.M. and Fallahi, M. (1999). Wound healing properties of Elaeagnus angustifolia. Journal of Pharmacology, 51, 128.

Selvan, D.A., Mahendiran, D., Kumar, R.S. and Rahiman, A.K. (2018). Garlic, green tea and turmeric extractsmediated green synthesis of silvernanoparticles: Phytochemical, antioxidant andin vitrocytotoxicity studies. Journal of Photochemistry \& Photobiology, B: Biology, 180, 243-252.

Siegel, R.L., Miller, K.D. and Jemal, A. (2019). Cancer statistics 2019. Cancer Journal for Clinicians, 69, 734.

Tepe, H.D. and Doyuk, F. (2020). Determination of Phytochemical Content by Chromatographic Methods and Antioxidant Capacity in Methanolic Extract of Jujube (Zizyphus jujuba Mill.) and Oleaster (Elaeagnus angustifolia L.). International Journal of Fruit Science, 20(3), 1876-1890.

Wafa, I.A.F. and Ghareib, W.A. (2018). On the anticancer activities of silver nanoparticles. Journal of Applied Biotechnology and Bioengineering, 5(1), 43-46.

Wan, H., Williams, R., Doherty, P. and Williams DF. (1994). A study of the reproducibility of the MTT test. Journal of Materials Science: Materials in Medicine, 5, 154-159.

Wei, L., Lu, J., Xu, H., Patel, A., Chen, Z.S. and Chen, G. (2015). Silver nanoparticles: synthesis, properties, and therapeutic applications. Drug Discovery Today, 20(5), 595-601.

Zhang, H., Chen, S., Jia, X., Huang, Y., Ji, R. and Zhao, L. (2021). Comparation of the phytotoxicity between chemically and green synthesized silver nanoparticles. Science of The Total Environment, $752,1-8$

\section{Figure Legends}

Figure 1: A) Elaeagnus angustifolia fruit. B) The part of Elaeagnus Angustifolia fruit. C) The preparation of Elaeagnus Angustifolia fruit aqueos extract

Figure 2: UV-Vis spectrum of silver nanoparticles synthesized with aqueous extract of Elaeagnus angustifolia fruit 
Figure 3: FTIR spectrum of silver nanoparticles synthesized with aqueous extract of Elaeagnus angustifolia fruit

Figure 4: SEM micrograph of silver nanoparticles synthesized with the Elaeagnus angustifolia fruit aqueous extract

Figure 5: A) EDX spectrum of silver nanoparticles synthesized with Elaeagnus Angustifolia fruit aqueous extract. B) Elemental analysis results

Figure 6: A) IC50 plots of HELA, PC3 and L929 cells treated with silver nanoparticles. B) Cell viability graphs of HELA, PC3 and L929 cells treated with silver nanoparticles. C) Inverted microscope images of HELA cervical cancer cells treated with silver nanoparticles 